\title{
LIGEROS DATOS
}

sobre

LOS CRIADEROS DE PEÑOLES (Oax.) y TAMAZULA (Jal.),

por Jerónimo Híjar.

Por ser estas dos localidades relativamente poco conocidas, me creo en el deber de presentar á la Sociedad Geológica un resumen de las observaciones que hice en ellas el año próximo pasado; pues entiendo que debemos coleccionar aquí toda clase de informes que tengan alguna relación con la Geología, aun cuando su objeto haya sido meramente industrial. Hasta hoy ha faltado un centro que reuna todos los estudios hechos aisladamente por los ingenieros; resultando de ahí que los informes se pierden en su mayor parte, cuando han pasado algunos años después del incidente comercial ó minero que los motivó, y mucho trabajo gastado estérilmente.

Es verdad que semejantes estudios distan bastante, en lo general, de merecer el nombre de «geológicos;» pero también es cierto que suelen contener las únicas referencias escritas que pueden encontrarse sobre determinados lugares del País. 
El pueblo de Peñoles está situado en el Distrito de Etla, Estado de Oaxaca, como á cincuenta kilómetros de distancia, al W.N.W. de la capital del Estado, sobre el río de su nombre. La región en que se encuentra es montañosa, de clima templado, y está suficientemente provista de agua, en todas las épocas del año, por el citado río y sus afluentes.

El gneiss es la roca predominante y casi exclusiva, pudiendo vérsele más ó menos abundante en cuarzo y, en ocasiones, escaso de mica, ó bien con este elemento muy alterado, sobre todo en la proximidad de las vetas. Son éstas siempre de matriz cuarzosa exclusivamente, con estructura cristalina, é impregnada en diversos grados por óxidos de hierro. Contienen oro nativo en granos muy pequeños, diseminados en la matriz y no perceptibles á la simple vista; este oro es fácilmente amalgable en todas las muestras que recogí.

Un compañero de profesión se ha servido informarme que, algo más al Sur de donde yo anduve, examinó una veta robusta, de rumbo E.W. y $45^{\circ}$ de inclinación al Sur; habiendo encontrado en un tramo de doce metros á rumbo, que una mitad de la veta (la del «alto») tenía los mismos caracteres ya indicados: 1lenamiento de cuarzo ferruginoso aurífero, mientras que la mitad, contigua al «respaldo » bajo, consistía en cuarzo blanco con pirita de hierro y algo de sulfuro de plata. Yo no encontré ningún mineral de plata. .

La extensión del terreno que atraviesan las vetas de Peñoles no podré precisarla; pero es de consideración: sólo la zona mineralizada que recorrí al Sur y al Oriente del 
pueblo, comprende una área de más de treinta y cinco ki. lómetros cuadrados, siendo esto una fracción pequeña del mineral; pues tengo noticias fidedignas de que se dilata mucho más al N.W. y al S.E.

Se encuentran vetas de muy diversas potencias, desde unos pocos centímetros hasta diez ó más metros, no siendo escasas las que exceden de setenta y cinco centímetros.

Parece que hay en Peñoles tres sistemas de fracturas, ocupadas por vetas de llenamientos idénticos: unas, con rumbo medio de N.W. $23^{\circ}$ S.E., con inclinaciones comprendidas entre $44^{\circ}$ y $60^{\circ}$ al S.W.; otras, N.E. $25^{\circ}$ SW., con fuerte inclinación ó enteramente verticales; y otras, E.W., con $45^{\circ}$ de inclinación al Sur.

Todas las muestras que tomé, de las distintas vetas, acusaron mayor ó menor cantidad de oro en el ensaye: desde uno hasta más de cien gramos por mil kilogramos. Las leyes más elevadas correspondieron á muestras sacadas de las pequeñas excavaciones practicadas por los «lupios.» En la mayoría de los ejemplares había bastante oro para poder distinguirlo fácilmente, concentrando en la cuchara un puñado de cuarzo molido.

Puede distinguirse con facilidad el cuarzo más rico, porque no es compacto, sino que presenta numerosas caras ó planos de separación; ó bien es francamente careado; ó bien, por último, no tienen consistencia los fragmentos grandes, sin que se desagregan con una ligera presión; y, en todo caso están más ó menos teñidos de pardo rojizo ó de amarillo naranjado por la limonita. El gneiss del respaldo alto de una de las vetas, contenía en cierto lugar bastante oro para que pudiera verse en el ensaye de cuchara. 
Los lupios han abierto en Peñoles buen número de excavaciones poco profundas, de donde extraen el mineral aurífero que benefician en arrastres; pero limitándose siempre, como puede suponerse, á trabajar en los puntos muy favorables. Ultimamente ha emprendido trabajos sobre aquellas vetas una compañía más formal; pero puede decirse que la región minera de Peñoles, en su conjunto, está virgen todavía y presenta un interés considerable, puesto que contiene una notable cantidad de vetas de la formación cuarzosa aurífera piritosa, atravesando una roca granitica, estando comprendidas en este grupo las vetas de los campos auríferos más productivos del Mundo. Creo que Peñoles llegará á ser un centro importante de producción de oro.

Los otros criaderos á que voy á referirme se encuentran en la parte septentrional de la hacienda de Contla, entre Tamazula y Mazamitla (9. ${ }^{\circ}$ Cantón del Estado de Jalisco).

Estos criaderos consisten en vetillas angostas, cuyos respaldos se definen muy bien, y van acompañados de salbandas delgadas; la potencia máxima de las vetillas es de veinte centímetros, y suele reducirse á unos cuantos milímetros; siendo, en promedio, de tres á cinco centímetros. Tienen una dirección aproximada de N.W. $40^{\circ}$ S.E. y se inclinan como $75^{\circ}$ al N.E., cortando francamente y dislocando, las más veces, á las pizarras metamórficas de la región. Algunos de estos hilos se observan en concor- 
dancia con la estratificación de las pizarras, en puntos donde éstas tienen fuerte inclinación.

La matriz es principalmente cuarzosa y, en parte, calcárea; conteniendo: argentita, pirargirita, estefanita, pirita de hierro y chalcopirita; esta última en pequeñas cantidades y, todavía con más rareza, manchas de azurita y malaquita. Los cristales de todas estas especies suelen encontrarse bastante perfectos en las vetillas, y asociados frecuentemente con cristalizaciones de calcita.

Como estos pequeños filones paralelos están separados entre sí por decenas y aun centenas de metros, la explotación de cada uno, teniendo que ser independiente de la de los otros, resulta incosteable, á pesar de las altas leyes, por lo reducido del criadero. Sin embargo, la riqueza de uno de estos hilos ha sido suficiente para que en él se hayan llevado á cabo pequeños disfrutes, junto á la orilla derecha del arroyo del Malentón y casi al pie del salto principal.

Lo que hay de muy interesante en este arroyo, es su constitución geológica: está formada la montaña, á los dos lados del arroyo, por pizarras metamórficas, de color pardo ó azul negruzco, que en su conjunto presentan poca inclinación de S.W. á N.E.; pero que, en algunos puntos, están bastante erguidas ó caprichosamente corrugadas. Además de las vetillas á que hice referencia, cortan á estas pizarras, dislocándose también, varios diques y simples fallas, de rumbos parecidos al de las vetillas y de inclinaciones considerables.

Los diques están formados por una roca compacta, de color verde claro y aspecto litoide, que tuvo la bondad de 
estudiar el Sr. Ordóñez, describiéndola así: «está constituida de una masa microcristalina de cuarzo y feldespato, característica de la felsita ó litoidita; contiene pedazos de cristales de cuarzo y feldespato. Su aspecto general al microscopio permite considerar que la roca se relaciona á un magma rhyolítico, y que la cristalización de su pasta (microcristalina) procede de las condiciones físicas realizadas por su modo de yacimiento.»»

Lo que hay de más notable es la existencia de una roca, verde obscura, compacta, que, en un principio, tomé por una variedad de la roca estratificada metamórfica, debido á la semejanza de sus colores y á la concordancia de sus lechos, en los dos lugares en que la encontré. Posteriormente, habiéndola estudiado el Sr. Ordóñez, se sirvió describírmela así: «Al microscopio presenta el aspecto lampofírico, característico de las rocas en diques ó en capas intrusivas. En efecto, está constituida de una agrupación holocristalina de cristales microlíticos de oligoclasa, con un mineral ferromagnésico, que su alteración no permite reconocer claramente, pero que puede presumirse sea una piroxena. La alteración ha transformado principalmente dicha piroxena en clorita y en calcita. La roca, por su aspecto, se relaciona á las camptonitas, como una variante de las porfiritas andesíticas. si se puede demostrar su origen de capa intrusiva.»

Como se ve, si mi observación es exacta, habré encontrado un ejemplar digno de más minucioso estudio, de las capas intrusivas descritas por los geólogos americanos. 